Dr PAWEŁ WAWRYSZUK, adjunct

Institute of History and International Relations

Kazimierz Wielki University, Bydgoszcz, Poland

pawel.wawryszuk@gmail.com

originalan naučni rad

UDK: 327(497.1:438)"1956/1958"

primljeno: 12. februar 2018.

prihvaćeno: 16. maj 2018.

https://doi.org/10.29362/ist20veka.2018.2.waw.139-154

\title{
NORMALIZATION OF POLISH-YUGOSLAV RELATIONS AFTER WLADYSŁAW GOMULKA'S RETURN TO POWER (1956-1958)
}

ABSTRACT: The aim of this article is to present the process of political rapprochement between the People's Republic of Poland and Yugoslavia after political changes in the Soviet bloc in 1956. Gomulka's return to power resulted in high hopes in Belgrade. The Yugoslavs appreciated his political views similar to their ideas of "the construction of socialism" taking into account local conditions. It soon turned out, however, that his independent position had limits.

KEYWORDS: Polish-Yugoslav relations, Władysław Gomułka, People’s Republic of Poland, Federal People's Republic of Yugoslavia

\section{Introduction}

Belgrade was pleased with the fact that Gomulka returned to power in the party and in Poland after the decisions of the 8th Plenum and that he correctly arranged relations between the Polish United Workers' Party (PUWP) and the Communist Party of the Soviet Union (CPSU).

This situation could mean the improvement of Polish-Yugoslav relations, which were put to the test after the removal of the Communist Party of Yugoslavia (CPY) from the Communist Union (CU) in 1948. Poland and Yugoslavia used a good political climate of change in 1956 to get closer together. They continued to accept delegations at all levels, and reactivated cultural, economic and scientific relations.

\section{Political climate}

The visit of representatives of the Central Committee of the League of Communists of Yugoslavia (CC LCY) in Poland on 19-29 December 1956 was the most important event. It was headed by a member of the Executive Committee of the CC LCY, Svetozar Vukmanović-Tempo, and a member of the Ideo- 
logical Commission of the CC LCY, Stana Tomašević. The visit was symbolically a "new opening" in their mutual relations. The Polish hosts were Roman Zambrowski, Stefan Jędrychowski, Jerzy Morawski (former members of the Central Committee of the PUWP) and Władysław Matwin, then secretary of the Central Committee. On the last day of the visit there was also a meeting in the Political Bureau of the Central Committee of the PUWP (CC PUWP). Its result was a promise to extend topics of consultations in the future, including ideological ones. They were the most important obstacles to full normalization so far. On the other hand, it was clear that both sides would not change essentially their opinions. It was also confirmed by the use of official formulas such as "possibility of reaching socialism in various ways", "cross-party discussion" or "constructive criticism" to improve "theory and practice of socialism". The important issue - especially for Yugoslavia - was the PUWP's recognition of the principle of non-interference in the internal affairs of other parties, although this principle was repeatedly violated in the future. It was also recognized that "bilateral party relations in current conditions are the most appropriate forms of cooperation between communists and workers' parties". 1

The importance of talks was highlighted by a large number of articles in Yugoslav press. ${ }^{2}$ Their content had "a special meaning" - according to the press for Yugoslavia. There was one interesting article, in which it was stated that despite various forms of building socialism "anyone who followed the development of theoretical and practical thought in both parties could name the results of Warsaw talks with a logical conclusion stemming from their policies. The results prove that both parties consistently use these general principles that can be the only [emphasis P.W.] basis for progress in the cooperation of particular workers' movements". ${ }^{3}$ However, apart from the official communiqué, both delegations prepared a more detailed statement on the relations between the LCJ and the PUWP. ${ }^{4}$

Both parties stated that they should introduce elements of transparency in mutual relations, which was a novelty. The aim of this transparency was to inform the public about current cooperation and problems arising from it and to avoid the situation from the time of the conflict between the LCY and the Cominform, although such statements were propaganda rather than the actual situation. The same was true for the postulate of "the necessity to separate inter-party and inter-state relations". 5 The Yugoslav diplomacy was very keen on using this statement. It was a pragmatic postulate, and it resulted from political tactics and image issues, although in practice the idea of "separation" between the party and the government never took place, which was particularly evident during the

\footnotetext{
${ }^{1}$ Archiwum Akt Nowych (AAN), Wydział Zagraniczny Komitetu Centralnego Polskiej Zjednoczonej Partii Rabotniczej (WZ KC PZPR), XIA/42, Komunikat o rozmowach pomiędzy delegacjami KC ZKJ i KC PZPR, pp. 54-55.

${ }^{2}$ Politika, 31. 12. 1956.

${ }^{3}$ Ibid.

${ }^{4}$ AAN, WZ KC PZPR, XIA/42, Wspólne oświadczenie o stosunkach między Związkiem Komunistów Jugosławii a Polską Zjednoczoną Partią Robotniczą, pp. 45-47.

${ }^{5}$ Ibid., pp. 49-50.
} 
Czechoslovak crisis in 1968. If they implemented it, the LCY and the PUWP could differ ideologically or programmatically and maintain a certain distance at the ideological level, but they would not interfere with the cooperation between countries. The attempt to introduce such a solution into Polish-Yugoslavian relations was in some sense logical, because it allowed the preservation of the ideological status quo and, at the same time, brought Yugoslav economy closer to socialist economies. Such a model of cooperation would be beneficial for Yugoslavia, which was struggling with the economic crisis.

The Embassy of Poland in Belgrade immediately began to examine the opinions of major Yugoslav politicians regarding their visit to Poland. Two conversations held by the secretary of the Embassy, Zygmunt Pietrusinski, in midJanuary 1957 with Stana Tomašević and Veljko Vlahović (a member of the Politburo) seem to be interesting. The fact, that thanks to Tomašević's decision, the Publishing Institute at the CC LCY decided to print a booklet with Gomułka's speech at the 8th Plenum, and also its resolutions, proved that her opinion about her visit in Poland was very positive. She was also impressed by the Polish industrial base, which - from the statement cited by Pietrusiński - "makes Poland achieve in the near future such results that no one has achieved", and if "they had in Yugoslavia the same industrial base, they would do miracles". ${ }^{6}$

In those somewhat favorable opinions we can also find another one, announcing a new trend in relations between Belgrade and Moscow. Referring generally to the "problems bothering the international workers' movement", Tomašević claimed (stating that this is her private position) that "the discussion that is going on is a bit too hot" and then added that "the leadership of the LCY is not going to continue this discussion". It comes to mind an obvious comparison to the situation at the beginning of the conflict between the Cominform and the LCY, when the latter avoided any escalations not to provide any pretexts to the opposing party". ${ }^{7}$ This was confirmed by Milorad Milatović (Ambassador of Yugoslavia in Warsaw) who was talking with Józef Winiewicz about SovietYugoslav relations at the end of 1956. According to Winiewicz, Milatović talked about the issue "with some despondency", but he stressed that "Yugoslavia does not want to create any separate Marxist-Leninist school; it does not

\footnotetext{
${ }^{6}$ Archiwum Ministerstwa Spraw Zagranicznych (AMSZ), Departament I, z. 7, w. 20, t. 188, Notatka z rozmowy przeprowadzonej w dniu 11 I 1957 r. z tow. Staną Tomašević - członkiem Komisji Ideologicznej KC ZKJ i Z. Pietrusińskim - Radcą Ambasady PRL w Belgradzie, p. 28-29. She also added that the contacts between the PUWP and the LCY had a special character, as no other party had such a wide possibility of contacts at the highest level in the Central Committee of the LCY. In particular, Yugoslavia was interested in the process of gradually removal of the conservative faction, i.e. the "consolidation" process. Milatović emphasized the position of Marian Naszkowski, who- during the conversation with him- had to say that they [conservatives] should get a second chance, submit self-criticism and continue their work in the party. Anyway, according to Naszkowski cited by the Yugoslav ambassador: "there is no illusion that the party will avoid [influence - editor. P. W.] to the right or to the left ", but it will be much harder for „natonińczycy” to rebuild their former positions, see: Arhiv Jugoslavije (AJ), fond 507, CK SKJ, IX,101/I-56, Pismo br. 218, 21. V 1957, 1.

${ }^{7}$ Ibid., p. 30.
} 
want to create - under its leadership - a separate group of socialist states". What is more, Yugoslavia did not intend to impose its political solutions to anyone, although it did not renounce the pride of its own path to socialism which would be its contribution to the "victory of the socialism in the world". 8

\section{General trends in mutual relations}

The development of Polish-Yugoslav relations after the 8th Plenum of the Central Committee of the PUWP had a general character. Both countries had serious economic problems multiplied by turbulent events of October and November 1956 and an upcoming winter. For Yugoslavia, it meant a potential possibility of increasing the workers' dissatisfaction (which was not mentioned earlier in the previous telegrams). Therefore, in Belgrade, it was decided to extend the salary increase by 5-10 percent for other professions at the beginning of 1957. It was also decided to limit the influence of workers' councils by changing their decisions at the central level. There was too little restriction on investment at the expense of individual consumption. ${ }^{9}$ The Trade Unions' Central Office was dissatisfied - trade unions were still loyal towards the authorities, but they started to demonstrate different points of view, with the possibility of exacerbating their protest.

We should ask, which essential problems of foreign policy of both countries became opportunities and barriers in the development of mutual relations. The PUWP would benefit from the experience of its Yugoslav counterparts, because Yugoslavia had proper contacts with Western countries and international organizations. ${ }^{10}$ The issue of contacts with other workers' parties in capitalist countries was a part of a coherent tactic in strengthening the broadly understood workers' movement in the world. One of the elements recognized by Belgrade as the "first step" to independent of foreign policy was the visit of Polish government delegation in Asian countries in April 1957. ${ }^{11}$ The above issues were less important than the recognition of Polish borders on the Odra and the Nysa Łużycka Rivers. It was the undisputed priority of Polish politics. Poland of course considered the Soviet Union as a guarantee of the western border, but Warsaw tried to gain much wider support for this issue also outside

\footnotetext{
${ }^{8}$ AMSZ, Departament I, z. 7, w. 20, t. 189, Notatka nr 31 J.W., Warszawa, 8 XII 1956 r., p. 90.

${ }^{9}$ AMSZ, Departament I, z. 7, w. 21, t. 194, Notatka o sytuacji wewnętrznej Jugosławii, pp. 145-146.

${ }^{10}$ It is also about organizations of lesser importance than the larger ones, such as Yugoslavia's desire to join Poland to the World Veterans Federation (FMAC). This was a particular interest of Yugoslavia itself, striving for greater balance of "progressive" and capitalist forces. The vote on the French project on the decentralization of the Food and Agriculture Organization (FAO) was similar. Coordinating its position with Yugoslavia, in the first half of 1957 Poland also took part in the meetings of the Executive Committee of the World Energy Conference (in Belgrade) or the International Organization of Military Medicine conference in mid-1957. The Yugoslav government, invited by Warsaw, gained the status of observer during the eighth session of the Council for Mutual Economic Assistance (Comecon) in June 1957 in Warsaw.

${ }^{11}$ Borba, 10. 4. 1957.
} 
the Soviet bloc. Yugoslavia's support in this respect was not without significance, because it had special relations with Western countries. This aspect was important because Yugoslavia de iure did not recognize the Polish western border so far. It was a fact despite a series of official and unofficial statements of Tito and the most important state officials, who considered the case as closed. ${ }^{12}$

The development of relations between the Soviet Union and its satellites was not without significance. It was very important for Belgrade and often discussed in conversations with Polish diplomats, who in turn pointed to the incomprehension of the whole issue by the Yugoslavs. During one of the conversations with Polish diplomats, an employee of the Ministry of Foreign Affairs named Velić (her official rank was not established) was to state that under present conditions "the existence of an equal relationship between the USSR and the countries of the socialist community is excluded". This conversation was also one of the first suggestions or even disappointed hopes that in the relations with the USSR it was not possible to develop greater independence. This was particularly evident in the Polish-Soviet Declaration of November 18, 1956 about the status of Russian troops stationed in Poland. ${ }^{13}$ Yugoslav interlocutors defined the temporality of soldiers' stay as a return to the old forms of mutual relations and a direct threat to the sovereignty of the country, because "at any moment they [Soviet troops P.W.] could march to Warsaw". ${ }^{14}$ In a way, the emphasizing the importance of Polish-Yugoslav relations was expressed by Gomułka for party activists in Warsaw on November 29, 1956. He said then, and it was very clearly underlined by Yugoslav diplomacy, that "in the relations with Yugoslavia, we are dealing not so much with the normalization but with the erasure of everything that divided our

12 Yugoslav authorities counted on the economic cooperation with the FRG, hence they were forced to create carefully their policy in this area.

${ }^{13}$ An appropriate bilateral agreement sanctioning the above-mentioned issue was concluded in Warsaw on December 17, 1956 by Adam Rapacki (head of the Ministry of Foreign Affairs) and marshal Marian Spychalski, and on the Soviet side by their counterparts - Dmitry Szepiłow and Gieorgij Zhukov; full text of the agreement, see: Umowa między Rzadem Polskiej Rzeczypospolitej Ludowej a Rzadem Zwiazku Socjalistycznych Republik Radzieckich o statusie prawnym wojsk radzieckich czasowo [emphasis - P.W.] stacjonowanych $w$ Polsce, Dz. U. z 1957 r., nr 29, poz. 127 or in Internet:http://prawo.legeo.pl/prawo/umowa-miedzy-rzadem-polskiej-rzeczypospolitej-ludowej-arzadem-zwiazku-socjalistycznych-republik-radzieckich-o-statusie-prawnym-wojsk-radzieckichczasowo-stacjonowanych-w-polsce-podpisana-w-warszawie, 30 XI 2013.

${ }^{14}$ It should be noted some dichotomy in Yugoslav opinions. Milatović, as it was mention above, considered the stay of Soviet troops in Poland to be desirable - AMSZ, Departament I, z. 7, w. 20, t. 188, Notatka z przeprowadzonej w dniu $12 \mathrm{~V} 1957$ r. - rozmowy między pracownikami Ambasady: M. Jaworowiczem - attaché i K. Chodorkiem - ref. prasowym a zastępcą redaktora naczelnego „Večernjih novosti” - V. Popoviciem oraz pracowniczką tutejszego MSZ - Velić (stopnia służbowego nie mogliśmy ustalić), p. 38. In the Yugoslav circles there was also a joke told by the interlocutors of the Polish Embassy that Gomułka had to say that he was "ready to give away the sovereignty of the country for better geographical location". Both Polish diplomats had the impression that their interlocutors ,played" with them, hearing provocatively sounding questions and suggestions (eg whether staff changes at the Embassy of Poland are associated with dealing with the Stalinist faction and whether such a faction still exists in the Polish Embassy in Belgrade), but from the perspective of time it is impossible to agree with the Yugoslavs. 
countries in previous years". He suggested the lack of ideological differences, although he also pointed out that the development of mutual relations between Poland and Yugoslavia should not give any pretexts to the Soviet Union to put pressure on Poland. ${ }^{15}$ This document was released by the Yugoslav Ministry of Foreign Affairs in the first half of 1957 (as confidential, only for internal use). It was clear that Poland was still one of the closest partners of Yugoslavia among Eastern countries, and it constantly protested against the isolation of Yugoslavia in the light of Hungarian events. It was emphasized that the press took neutral positions, admittedly publishing more important articles on the subject, but without comments and exposing them too much. ${ }^{16}$

On February 1, 1957, the 7th Plenum of the CC of the LCY was held, which was largely confidential, as the merits of the meeting were not made public. The reason was its main theme, namely, the relations of the LCY with other communist and workers' parties and issues related to a forthcoming party's congress. Of course, the first issue was primarily related to the growing polemic between the LCY and the CPSU at the beginning of the conflict between them. Documents from meetings were available for selected parties with a more subdued position and, understandably, sent to Warsaw. ${ }^{17}$

In any case, Polish party leadership was widely informed by the Yugoslavs about the rise of the conflict. Milorad Milatović used every opportunity to present Yugoslav views. During the reception at the Italian Embassy, he repeatedly asked Maria Wierna about this issue. The ambassador described the first quarter of 1957 as "an attempt to isolate Yugoslavia". He added that "Yugoslavia is not responsible for the public conflict and it is not interested in fueling it but Yugoslavia cannot be silent because it will be considered as its weakness". ${ }^{18}$ Gomułka also did not agree with public polemics, and he considered them to be harmful. Although there was still no any sign of the cooling of the relations between Warsaw and Belgrade, some Poland's moves could herald a change in its policy in this respect or it could result from the "hypersensitivity" of the Yugoslav diplomat. He told Wierna that he was speaking without any subtext and then asked her about the purposefulness of the publication of Bułganin speech during his stay in Hungary (on March 27, 1957). Then a lot of bitter words were said about Yugoslavia without any editorial commentary and, at the same time,

\footnotetext{
${ }^{15}$ AJ, 507, CK SKJ, IX, 101/II-49, Narodna Republika Poljska (Priručnik), Beograd 1957, 63.

${ }^{16} \mathrm{Ibid}$.

${ }^{17}$ AMSZ, Departament I, z. 7, w. 20, t. 188, Notatka z rozmowy przeprowadzonej z V. Vlahoviciem członkiem CK ZKJ, k. 35. Milatović also confirmed the reluctance of the Polish authorities to isolate Yugoslavia again. According to them, it did not bring the desired results. The evidence was to be proved by talks between the LCY and the Communist Party of France (KPF), when French communists recognized the policy led by the Yugoslav leadership, see: AJ, 507, CK SKJ, IX,101/I-51, Pismo br. 151, 173/22, Warszawa, 10. IV 1957, k. 2.

${ }^{18}$ ASMZ, Departament I, z. 7, w. 20, t. 188, Notatka ze spotkań z Ambasadorem Jugosławii Milatoviciem (na przyjęciu w Ambasadzie Włoch) i z radcą Ambasady Taborem/ w MSZ/ w okresie 1316 IV b.r. (1957), pp. 91-92.
} 
there were "barely" shortcuts of Yugoslavian articles published in "Borba" ${ }^{19}$ It can be thought that the diplomat's behaviour was caused by a real fear (as it turned out to be unfounded) of the change of Polish policy towards Yugoslavia.

Poland also attributed the Polish-Yugoslav relations an appropriate rank. The issue was the same from the perspective of Yugoslavia, because Poland remained its closest partner among Eastern countries. Gomułka and Polish communists advised the Yugoslavs to avoid annoying polemics, but "the Soviet companions - as Milatović claimed - must see Yugoslav teeth". ${ }^{20}$ Warsaw did not fully agree with such a view. Yugoslavia with great attention maintained the Soviet-Yugoslav relations, but in turn Polish-Yugoslav relations could not be „,infinitely" developed at the expense of Poland's contacts with the Soviet Union. The Polish Foreign Ministry drew its attention to this and sent instructions to Belgrade: "In 1957, the policy of further rapprochement and development of our relations in all areas of political, economic and cultural life should be continued. In the implementation of these assumptions, our activity meets an exceptionally favorable atmosphere, which also includes some elements that do not suit us, namely, the Soviet attempts to isolate Yugoslavia created a tendency to build a Yugoslavia-Poland bridge. In this situation, it is advisable to be very flexible in mutual rapprochement and changes in the position of Yugoslavia in its relations with the USSR". ${ }^{21}$

The state of relations between Belgrade and Moscow was also a concern among the activists of the middle-level of the PUWP, who were not specified by the Yugoslav Ministry of Foreign Affairs. Those activists expressed their concerns about the development of the situation and, more importantly, that Yugoslavia itself, to some extent, contributed to the worsening of mutual relations. At the same time, it was added that disputes should be resolved on a constructive discussion basis and without any public, which could only harm the common interest. Gomułka and Ochab's statements during the 9th Plenum of the PUWP on May 15-18, 1957, gained recognition. At that time, they confirmed the harmfulness of the possible isolation of Yugoslavia, this isolation could worsen Polish-Yugoslav good relations and weaken the position of Poland in the relations with the USSR. ${ }^{22}$ This was not in the interest of Yugoslavia, and it tried to avoid pretexts to use this issue against Poland.

Anyway, the mutual cooperation developed without much difficulty. In mid-1957, an agreement was signed between two dailies "Ekonomska politika" and "Życie Gospodarcze". According to the agreement, the newspapers committed themselves to introduce a column about a given country with information

${ }^{19}$ Ibid., pp. 92-93.

${ }^{20}$ AMSZ, Departament I, z. 7, w. 20, t. 189, Notatka nr 61/JW., 23 IV 1957, pp. 98-99.

${ }^{21}$ AMSZ, Departament I, z. 7, w. 20, t. 191, Wytyczne dla pracy Ambasady PRL w Belgradzie na rok 1957, p. 61.

${ }^{22}$ AJ, CK SKJ, Narodna Republika Poljska..., 64. About the internal situation in the party before the Plenum in the opinion of the Yugoslav Embassy, see: Diplomatski arhiv Ministarstva spoljnih poslova Republike Srbije (DA MSP), Politička arhiva (PA), 1957, Poljska, Ambasada FLRJ w Warszawie, f. 71, sf. 13, br. 49960, Pismo br 218, 4. 5. 1957. 
on the most important economic events, including directions of economic development. What is even more important: about "interesting theoretical discussions on important issues of the economic model of Poland"; Polish economists' discussions over the essence of this model [emphasis P.W.], and "opinions and comments (including critical) of Polish economists over Yugoslavia's economic policy, and its system". ${ }^{23}$ Although there may be some objections about the agreement, it was the first one concluded between Yugoslavia and another country from the Soviet camp. ${ }^{24}$

\section{The peak period in the process of normalization}

As for the Polish borders on the Odra and the Nysa Łużycka rivers, the situation was still complicated for Yugoslavia. Yugoslavia intended to maintain at least good economic relations with the Federal Republic of Germany (FRG). These relations could break if Belgrade accepted the existence of the GDR. The Polish diplomacy saw the possibility of solving the problem and presented political benefits for Yugoslavia proposing "strengthening the unity of socialist countries", but it was not the best argument for Yugoslavia. ${ }^{25}$ Yugoslavia played some role in the process of normalization of Polish-West German relations. Probably this issue should be explored more deeply, but in 1957 the Embassy of Yugoslavia in Washington mediated in talks with the representative of West Germany, Albrecht von Kessel, and confidential meetings were held in private apartments of Yugoslav diplomats ${ }^{26}$, however, in Yugoslavia, for example, the names of towns and villages in the timetable of trains happened to be written in German although they were then in Poland.

Interestingly, the problem of recognition of the Polish western border in Yugoslavia was partly connected with the visit of Cardinal Stefan Wyszyński in Rome, which began on May 6, 1957, and lasted over a month. It should be noted that the relation between the state and the Catholic Church in Yugoslavia was a much larger political problem than in Poland. It was connected mainly with accusations of many church hierarchs for collaboration with occupiers, especially in Croatia and Slovenia. The information about the visit of Wyszynski was published in the Yugoslav press on the first pages, what should be considered as a measure of the importance of the visit for the authorities. Belgrade

${ }^{23}$ AMSZ, Departament I, z. 7, w. 20, t. 188, Notatka służbowa z rozmowy między redaktorem Jašą Daviciem z „Ekonomskiej politiki” a pracownikiem Ambasady K. Chodorkiem, 15 VII 1957 r., p. 43.

${ }^{24}$ The formula for sending relevant texts from one editorial office to another and publishing them on the basis - "Życie Gospodarcze” for "„Ekonomska politika"“ (and vice versa) was agreed, both parties reserved the right to shorten or rewrite (in a "small" scope) texts, as a rule it should be called censorship.

${ }^{25}$ AAN, WZ KC PZPR, XIA/42, Stosunki polsko-jugosłowiańskie, pp. 29-30.

${ }^{26}$ Wanda Jarząbek, „W poszukiwaniu porozumienia z Republiką Federalną Niemiec - tajne rozmowy z Albrechtem von Kesselem w Waszyngtonie w 1957 roku”, Rocznik Polsko-Niemiecki, nr 8, (1999), 205-215; Idem, Polska Rzeczpospolita Ludowa wobec polityki wschodniej Republiki Federalnej Niemiec $w$ latach 1966-1976. Wymiar dwustronny i międzynarodowy (Warszawa: Instytut Studiów Politycznych Polskiej Akademii Nauk, 2011), p. 24 and next. 
noticed that relations with the Episcopate improved in Poland after the October 1956, and a "new quality" was introduced, which could be an example of "a proper creation of relations between the socialist state and the Church"27.

In Belgrade, the most important problem in political relations between Poland and Yugoslavia in 1957 was the consolidation in the PUWP, which was inseparably connected with the issue of "conservatism" in the party. The proof of this was the results of parliamentary elections in Poland on January 20, 1957. They were supposed to testify "the unity of the nation on the platform of independence", but also the "hard" fight against "extreme tendencies". ${ }^{28}$ This was also confirmed by Ambassador Henryk Grochulski in an interview with Vlahovic. He stressed the necessity of the "consolidation" in the party. ${ }^{29}$ Velić stated that "our party [PUWP] does not exist in the Marxist sense [...], it is a conglomerate of factions such as Stalinists, anarchists". ${ }^{30}$ Similar conclusions came from the Yugoslav diplomatic representation in Ankara, which underlined the attacks on Gomułka by the "natolińczycy", but not by their "most important leaders", but by "peripheral Mijal". 31

The Yugoslav diplomacy seemed to overestimate the importance of conflicts within the PUWP and the political situation in Poland. One of the political reports of the Embassy of Yugoslavia in Warsaw stated that the victory in the January parliamentary election "was not a proof of the party's organizational and political power". It emphasized that "a significant number of votes for the list of the National Unity Front was not a vote for socialism" (sic!), October was only the "first stage" in creating a "liberal-bourgeois" Poland, and only Poland's fear of the USSR stopped such tendencies. ${ }^{32}$ It was not an isolated voice. Milatović suggested: "wide rehabilitation is being done, that's why various opportunist elements came to the fore in the Party." In this way, some former PSP (Polish Socialist Party) activists were called „opportunist elements”, and the party itself matured to the possibility of disintegration. The ambassador wrote to the head office on this subject many times in a similar spirit. ${ }^{33}$

${ }^{27}$ AMSZ, Departament Prasy i Informacji, z. 21, w. 53, t. 752, Notatka informacyjna na temat pierwszych głosów prasy jugosłowiańskiej w związku z wizytą kardynała S. Wyszyńskiego w Rzymie, pp. 1-6. More about the relations between the state and the Church from the Yugoslav perspective, see: AJ, 507, CK SKJ, Narodna Republika Poljska..., pp. 27-29.

${ }^{28}$ DA MSP, PA, 1957, Poljska, f. 71, sf. 1, br. 44585.

${ }^{29}$ AJ, 507, CK SKJ, IX, 101/II-59, Zabeleška o razgovoru druga Veljka Vlahovića sa ambasadorom Grochulskim 13. juna $1957 \mathrm{u}$ 10h, 1.

${ }^{30}$ AAN, WZ KC PZPR, XIA/42 Notatka służbowa z przeprowadzonej rozmowy w dniu $12 \mathrm{~V}$ 1957 r. - rozmowy między pracownikami Ambasady: M. Jaworowiczem - attaché i K. Chodorkiem - ref. prasowym a zastępcą redaktora naczelnego „Večernjih novosti” - V. Popoviciem oraz przedstawicielką tut. MSZ - Velić, p. 84.

${ }^{31}$ DA MSP, PA, 1957, Poljska, f. 71, sf. 1, br. 412397, p. 1. Ambasada FLRJ w Warszawie.

32 The document has a working character, which, however, casts some light on the activities of Yugoslav diplomacy in Poland, the stereotypical understanding of the political situation in the country by some diplomats, see: DA MSP, PA, 1957, Poljska, f. 71, sf. 4, br. 28955, Unutrašnja situacija, p. 1.

${ }^{33}$ DA MSP, PA, 1957, Poljska, f. 71, sf. 13, br. 4293, Pismo br. 3, 5. I 1957, 2, Ambasada FLRJ w Warszawie; Ibid., br. 4522, 1-2. 
In 1957 and the last months of the previous year, there were many visits to various organizations, including veterans, trade unions, etc. At the beginning of 1956, contacts between the Polish Union of Fighters for Freedom and Democracy (ZBoWiD) and its counterpart, the Union of the Fighters of the National Liberation War, were established. It was the time when two representatives of those organizations visited Warsaw. Interestingly, it was Yugoslavia that pushed for the exchange of official delegations. It even happened that the Yugoslav association intervened at the Polish Embassy in Belgrade on this matter. It was consulted with Aleksander Ranković, including the head of the security service, who gave the green light to tighten their cooperation. The proposed cooperation was of a qualitative nature. The idea was to establish working groups to exchange information on the functioning of both organizations, the structure of work, etc., and not to participate in demonstrations or special events. ${ }^{34}$

However, the visit of the ZBoWiD delegation in Yugoslavia did not take place until the turn of April and May 1957, and it lasted two weeks. The report from this visit underlined a very positive reception, far beyond the diplomatic protocol. The host was Ranković and even Tito invited the Polish delegation to his private residence the day before departure, although this meeting was not in the official plan. During the meetings, the topics were not only issues related to the activities of both unions, but also the economic situation in Yugoslavia, tasks and experiences of workers' councils or even the role of the LCY in social and political life of the country. There were also references to the international situation, including Tito`s assessment of changes in the Soviet Union in the economic aspect, and relations with the countries of the Eastern bloc. The Yugoslav leader underlined the "need to emphasize all connections of these countries and not to exacerbate differences, especially in the press". ${ }^{35}$

The visit of the delegation of the Union of the Fighters of the National Liberation War in Poland was held on September 19 - October 5, 1957. It had a similar character to the Polish visit of the ZBoWiD in Yugoslavia. Delegates visited a large part of Poland, including western territories (Wroclaw, Bolesławiec, where a significant number of repatriates from Yugoslavia settled, and Szczecin). Although the Yugoslav delegation was treated in a representative manner as it was with the Polish one in Yugoslavia, the talks focused mainly on issues related to activities of two Unions.

On September 10-16, 1957, the official governmental and party delegation headed by Gomułka was in Yugoslavia, with Cyrankiewicz, Rapacki and Ochab. The Polish diplomacy assessed this visit as follows: "it can be boldly said that - if the Polish-Yugoslav relations were successful so far, they entered

${ }^{34}$ AMSZ, Departament I, z. 7, w. 20, t. 175, Pismo Ambasady PRL w Belgradzie do zarządu Głównego ZBoWiD, nr L.392/117/J/56, 3 X 1956 r., p. 2.

35 The Yugoslavian Union of Fighters was quite influential, with about 1.2 million members at that time. The National Front and Trade Unions had stronger influences, because they were the main part of the Socialist Union of the Working People of Yugoslavia. More about the visit of the ZBoWiD in Yugoslavia, see Ibid., Notatka informacyjna o pobycie delegacji ZBoWiD w Jugosławii w dniach od 26 kwietnia do 10 maja 1957 r., pp. 10-17. 
into a period of friendship and broad cooperation in all fields". ${ }^{36}$ One of the results of the talks was the publication of the joint Declaration of 16 September, which stressed the principle of peaceful coexistence between the workers' parties and socialist countries, a general slogan about strengthening socialism in the world. The official recognition of the Polish borders on the Odra and Nysa Łużycka rivers was much more important, which in fact meant the recognition of the GDR. ${ }^{37}$ The published document was very important, as the entire visit, because it was the first event of this type and this rank between Yugoslavia and another country from the Eastern bloc. In particular, the recognition of the borders required sacrifice, because it resulted in breaking diplomatic relations with the FRG and the deep dissatisfaction of the United States and other Western countries, discrediting Yugoslavia as the "satellite of Moscow". It should be mentioned that for Yugoslavia, economic contacts with the West and its financial support were very important. The US Ambassador in Belgrade, James W. Riddleberger, was instructed to prepare a report on the political situation in $\mathrm{Yu}-$ goslavia in order to reconsider the legitimacy of providing assistance. He was also supposed to "brutally" intervene in the Ministry of Foreign Affairs against the rapprochement with the socialist camp. ${ }^{38}$

The first working meeting between Gomułka and Tito took place on the second day of the visit (September 11). ${ }^{39}$ The important topics were: the final establishment of the text of the Agreement on Friendship and Mutual Cooperation (the project was prepared by Poland), the creation of a joint agenda to coordinate economic cooperation, and the definition of cooperation principles at the enterprise level. In terms of party relations, the parties' cooperation was discussed in the perspective of the upcoming commemoration of the fortieth anniversary of the October Revolution in Moscow. In foreign matters, there were discussed the German question (most important), the cooperation between Yugoslavia and other socialist countries, the Syrian question, and the issue of the Baltic Sea as a sea of peace, which was one of the first peace initiatives discussed bilaterally. ${ }^{40}$ In ideological matters, Tito's recogni-

${ }^{36}$ AMSZ, Departament I, z. 7, w. 21, t. 194, Raport polityczny Ambasady PRL w Belgradzie za okres od 1 września do 30 listopada 1957 r., p. 178.

${ }^{37}$ The Polish delegation set as a necessary condition of the visit to recognize Polish western borders by Yugoslavia, see: Polskie Dokumenty Dyplomatyczne, 1957, eds. Krysztof Ruchniewicz and Tadeusz Szumowski (Warszawa: Polski Instytut Sprav Miedzynarodowych, 2006), 608609, Szyfrogram nr 8085, 24 VIII 1957.

${ }^{38}$ AMSZ, Departament I, z. 7, w. 21, t. 194, Raport polityczny Ambasady PRL w Belgradzie..., pp. 190, 195-196. The first information about the preparation of Gomułka's visit to Yugoslavia appears in February 1957, when Milatović was ordered to probe the possible nature and form of the Polish leader's visit. More about the plan of the visit, see: AJ, 507, CK SKJ, IX, 101/I-68.

${ }^{39}$ Tito accompanied the Polish delegation during the whole of its Yugoslavia tour, which, as it was emphasized, was an unprecedented activity of the head of Yugoslavia.

${ }^{40}$ AJ, 507, CK SKJ, IX,101/I-68, Beleška o razgovorima između delegacija CK SKJ i vlade FNRJ i CK PURP-a i vlade NR Poljske 11. IX 1957. u Beogradu, 20-28; AJ, fond 837, Kabinet Predsednika Republike (KPR), I K-72, J: 1183, Beleška o razgovorima između delegacija CK SKJ i vlade FNRJ i CK PUPR-a i vlade NR Poljske 11. IX 1957. u Beogradu, 1 i dalje. 
tion of Polish agricultural associations as a socialist form of farming in agriculture was essential. And Gomułka declared that Yugoslavia was not responsible for the conflict of $1948 .^{41}$

The Yugoslav press (and the Polish press) wrote about the visit in a very flattering way. It was written about Gomułka that "with sense and great revolutionary energy he removed two dangers threatening Poland: the old Stalinist bureaucratic system and anarchy". Thanks to him, "Poland is on the road to build a true socialist system, in accordance with its own Polish specificity". He was described as a man, "who always found so much strength to raise the high standard of his beliefs, to defend the purity and beauty of the idea." When the PolishYugoslav Declaration was signed, the press granted it an equal place in terms of political significance with the previous Belgrade and Moscow Declarations. ${ }^{42}$ Such a positive tone of press releases also had its deeper meaning. In Belgrade, the visit of the delegation was connected with the hope of discussing the relations between Yugoslavia and the camp, with Comrade ,Wiesław” as a mediator. ${ }^{43}$

\section{Towards "Yugoslav revisionism"}

Some certain discrepancies between Poland and Yugoslavia in the second half of 1957 can be observed in the assessment of Polish foreign policy by Yugoslavia. Generally speaking, Yugoslavia emphasized Poland's reasonable and balanced foreign policy, especially in relation to the countries of the socialist camp. Polish policy towards the USSR gained equally high appreciation, but the "tactical" elements were underlined. Namely, Warsaw "tactically agrees with the Soviet Union in its principles. The Soviet Union demands that we approve them, but in practice we are implementing the policy outlined by the VIII Plenum of the Central Committee of the PUWP". The proof of it was the signing of the declaration of the twelve parties (as discussed below) in Moscow in November 1957 by the PUWP. The proof was also information in the press referring to the spirit of the 8th Plenum, and ,writing about them and commenting on them, omitting those theses that refer to the USSR as the superpower of the socialist movement". ${ }^{44}$

This approach only partially coincided with the truth. It is a fact that Warsaw remained under the political control of Moscow (e.g. Soviet troops stationed

\footnotetext{
${ }^{41}$ Andrzej Skrzypek, Dyplomatyczne dzieje PRL w latach 1956-1989 (Pułtusk - Warszawa: Akademia Humanistyczna im. Aleksandra Gieysztora, 2010), 37.

42 AAN, WZ KC PZPR, XIA/42, Pismo nr DPI 5638/117/J/57, 16 X 1957, pp. 136-137.

${ }^{43}$ Polskie Dokumenty Dyplomatyczne, 1957, 610-611, Szyfrogram nr 10068, 28. VIII 1957.

${ }^{44}$ AMSZ, Departament I, z. 7, w. 20, t. 189, Notatka z rozmowy z towarzyszami jugosłowiańskimi Jose Bačiciem - I Sekretarzem Ambasady FLRJ i Perką Vitarović - kierownikiem sekcji polskiej w MSZ Jugosławii w dniach 7-9 I 1958 r., p. 102. The report prepared by the Embassy of Poland in Belgrade was a specification of the report which was to be handed to Milatović after his visit to Belgrade as instructions / recommendations. Such an opinion was confirmed by Roman Werfel, then head of the "Nowe Drogi", who said that Poland "is fighting a battle against two fronts", see: AJ, 507, CK SKJ, IX, 101/I-54, Pismo nr 269, 7 VII 1957 r., p. 1.
} 
in Poland). However, the degree of independence was various and it changed over time. Till October 1956, the authorities could not afford any real opposition to the Kremlin leaders, but Gomułka promoted independent initiatives at least in several aspects. They included borders and security issues without "major" consultations with Moscow. The mentioned declaration was signed during the fortieth anniversary of the October Revolution in Moscow, together with the "Manifesto of Peace" signed by Yugoslavia. ${ }^{45}$ The lack of signature of the Yugoslav delegation in the declaration was another proof of the worsening of Yugoslav-Soviet relations. In Belgrade, it was believed that this initiative was another attempt to control the policy of the Communist parties by Moscow. ${ }^{46}$ In the opinion of Yugoslav leaders, it was a symbol of returning to principles of the Cominform policy, which was totally unacceptable in Belgrade. ${ }^{47}$ Yugoslav diplomats described it as "the existence of fundamental discrepancies. Signing the declaration would be a prove that in 1948 the USSR was right, not Yugoslavia”. According to Jose Bačić, the first secretary of the Embassy of Yugoslavia in Warsaw, in the USSR "they cannot distinguish liquidators from people who criticize bad phenomena in socialism. And yet Yugoslavia and Poland fight with Đilas and Kołakowski". 48

The Yugoslav diplomacy was afraid of another attempt to isolate Yugoslavia by socialist countries. Tito was often to ask the Ministry of Foreign Affairs about the political situation in Poland. His behaviour may confirm that some administrative agendas analyzing the internal situation in Poland and other socialist countries were reinforced. ${ }^{49}$ Basing on Bačić's opinions, Belgrade's close-up with Warsaw was connected with ,the fear of worsening of relations with the USSR" in the face of the Congress. Yugoslav Communists were ready

45 The content of Gomułka's position was published in the pages of „Nowe Drogi”, see: Wyniki narady partii komunistycznych i robotniczych w Moskwie. Referat tow. Władystawa Gomulki na zebraniu aktywu partyjnego w Warszawie 28 listopada 1957 r., „Nowe Drogi” 1957, nr 12 (102), pp. 3-22.

${ }^{46}$ Michał Jerzy Zacharias, Komunizm - federacja - nacjonalizmy. System polityczny w Jugosławii 1943-1991. Powstanie - przeksztatcenia - rozkład (Warszawa: Neriton, 2004), 180; Robert Skobelski, „Polska wobec Jugosławii w latach 1956-1970, w: Polska między Wschodem a Zachodem, t. 2, W kregu polityki zagranicznej, editors Anna Szczepańska, Henryk Walczak, Adam Wątroba, (Toruń: Wydawnictwo Adam Marszałek 2008), 229-230; Halina Ognik, Polityka zagraniczna Jugostawii - aspekty europejskie (Warszawa: Panstowe Wydawn. Naukowe, 1986), 105; Đoko Tripković, Jugoslavija-SSSR 1956-1971 (Beograd: Institut za savremenu istoriju, 2013), 73-74.

${ }^{47}$ Khrushchev wrote completely different words in his memoirs: "We had no reason to conflict with Yugoslavia. After Stalin's death, we no longer aspired to the role of hegemon (in the communist movement), and we pursued a policy of non-interference in the internal affairs of Yugoslavia". Memoirs of Nikita Khrushchev, Vol. 3: Statesmen (1953-1964), ed. Sergei Chruszczow (The Pensylvania State University, 2007), 542. This seems inconsistent with the facts.

${ }^{48}$ AMSZ, Departament I, z. 7, w. 20, t. 189, Notatka z rozmowy z towarzyszami jugosłowiańskimi Jose Bačiciem - I Sekretarzem Ambasady FLRJ i Perką Vitarović - kierownikiem sekcji polskiej w MSZ Jugosławii w dniach 7-9 I 1958 r., p. 104. Some Polish communists (in this case it is Morawski) assessed negatively the fact of not signing the declaration by Yugoslavia, see: AJ, 507, CK SKJ, IX, 101/I76, Pismo br. 621, 31. XII 1957, 1.

${ }^{49}$ The issue concerns the Department of the Socialist Countries in the Yugoslav Ministry of Foreign Affairs and the Polish Department there. 
to present the LCY program in autumn 1957, although they were waiting for results of the November talks in Moscow. The first edition of the LCY program, prepared by Kardelj, was ready in October $1957 .{ }^{50}$ It was a tactical move, in line with the general strategy of Yugoslav diplomacy. What is more, Belgrade was aware of a potentially unfavorable reaction to the program. Officially, the reason of the postponement of the date of the Congress was elections to the local national councils. ${ }^{51}$

At the beginning of 1958 there were not any signals of the worsening of Polish-Yugoslav relations, and their mutual contacts were still developing in the spirit of talks from September. Trade agreements and cultural relations were carried out without any problems. Further exchanges of representatives in the field of scientific, technical, sports, and other areas were planned. Yugoslavia invited the Central Committee of the PUWP to the debate of the 7th Congress of the LCY. The Yugoslav authorities expected a critical reaction of the Soviet Union to the theses in the new statute of the LCY and a new line of the party. They hoped some communist parties would be positive towards the theses with the Polish party ahead. Yugoslavia's hopes were related to Gomułka's relatively independent policy towards the USSR. However, as history showed, the Polish leader also had limits of his independence.

\section{Conclusion}

The Polish-Yugoslavian rapprochement was a natural consequence of political changes in the Soviet bloc after Stalin's death and Khrushchev's dealing with the past during the 20th Congress of the CPSU. However, the loosening of Moscow-socialist countries relations were not limitless. It seems that Yugoslavia's hopes for this process and its perception Poland as a country that had the greatest chance to be free from the Soviet Union were too far-reaching. The geopolitical position of Poland made such a scenario impossible. However, both countries tried to lead correct relations after the period of conflict with the Cominform.

When it turned out that the ideological differences between the parties were still not eliminated, their new relations helped to avoid a conflict on a scale as it was in 1948. A specific modus vivendi was developed, which assumed the "separation" of party-government relations. Although it was seemingly contradictory, it gave the possibility of ideological differences while maintaining state relations, including - perhaps above all - economic ones. In practice, such a solution was implemented in 1958, when, to a large extent under the Soviet pressure, "Yugoslav revisionism" was announced.

\footnotetext{
${ }^{50}$ AMSZ, Departament I, z. 7, w. 20, t. 189, Notatka z rozmowy z towarzyszami jugosłowiańskimi Jose Bačiciem - I Sekretarzem Ambasady FLRJ i Perką Vitarović - kierownikiem sekcji polskiej w MSZ Jugosławii w dniach 7-9 I 1958 r., p. 105.

${ }^{51}$ AMSZ, Departament I, z. 7, w. 21, t. 194, Raport polityczny Ambasady PRL w Belgradzie za okres od 1 września do 30 listopada 1957 r., p. 178.
} 


\section{REFERENCES}

- Jarząbek, Wanda. „W poszukiwaniu porozumienia z Republiką Federalną Niemiec - tajne rozmowy z Albrechtem von Kesselem w Waszyngtonie w 1957 roku". Rocznik Polsko-Niemiecki, nr 8, (1999), 205-215.

- Jarząbek, Wanda. Polska Rzeczpospolita Ludowa wobec polityki wschodniej Republiki Federalnej Niemiec $w$ latach 1966-1976. Wymiar dwustronny $i$ międzynarodowy. Warszawa: Instytut Studiów Politycznych Polskiej Akademii Nauk, 2011.

- Memoirs of Nikita Khrushchev, Vol. 3: Statesmen (1953-1964). Editor Sergei Chruszczow. The Pensylvania State University, 2007.

- Ognik, Halina. Polityka zagraniczna Jugostawii - aspekty europejskie. Warszawa: Panstowe Wydawn. Naukowe, 1986.

- Polskie Dokumenty Dyplomatyczne, 1957. Editors Krysztof Ruchniewicz and Tadeusz Szumowski. Warszawa: Polski Instytut Sprav Miedzynarodowych, 2006.

- Skobelski, Robert. „Polska wobec Jugosławii w latach 1956 - 1970. W: Polska między Wschodem a Zachodem, t. 2, W kręgu polityki zagranicznej. Editors Anna Szczepańska, Henryk Walczak, Adam Wątroba, 220-235. Toruń: Wydawnictwo Adam Marszałek, 2008.

- Skrzypek, Andrzej. Dyplomatyczne dzieje PRL w latach 1956-1989. Pułtusk Warszawa: Akademia Humanistyczna im. Aleksandra Gieysztora, 2010.

- Tripković, Đoko. Jugoslavija-SSSR 1956-1971. Beograd: Institut za savremenu istoriju, 2013.

-Zacharias, Michał Jerzy. Komunizm - federacja - nacjonalizmy. System polityczny w Jugostawii 1943-1991. Powstanie - przekształcenia - rozkład. Warszawa: Neriton, 2004. 
Dr PAWEŁ WAWRYSZUK, adjunct

Institute of History and International Relations

Kazimierz Wielki University, Bydgoszcz, Poland

pawel.wawryszuk@gmail.com

\section{NORMALIZATION OF POLISH-YUGOSLAV RELATIONS AFTER WLADYSLAW GOMULKA'S RETURN TO POWER (1956-1958)}

\section{Summary}

Although a slow process of normalization of Polish-Yugoslav relations started after the death of Stalin in 1953, only the 1956 changes in the Eastern Bloc allowed for full normalization. It was manifested in all fields, especially political ones. A number of governmental and party delegations were exchanged with the visit of Władysław Gomułka in September 1957 in Yugoslavia. Yugoslavia engaged in an implicit mediation in negotiations between Poland and West Germany, although it still refused to formally recognize the Polish western borders for fear of undermining economic relations with the Federal Republic of Germany. In that field Yugoslav policy was careful.

In the first half of 1958, despite small misunderstandings, the ideological conflict was not visible in mutual relations. However, Yugoslavia opposed Moscow to improve relations with the entire socialist camp and this led to a recooling of Polish-Yugoslav relations. The expectations of the Yugoslav leadership, including even a favorably neutral position of the Polish United Workers' Party against the arrangements of the planned $7^{\text {th }}$ Congress of the League of Communist of Yugoslavia, proved to be wrong. Gomułka failed the hopes the Yugoslav government had. However, the geopolitical context of the situation of both countries must not be forgotten. There was a number of Soviet troops in Poland, Eastern Germany was a neighbor country, where as well those army was present. Until now it is not clear whether the relatively special position of the Polish government, as well as party, in relations with the Yugoslav, was caused by the decision of Kremlin. To answer that question needed is a research in Russian archives.

KEYWORDS: Polish-Yugoslav relations, Władysław Gomułka, People’s Republic of Poland, Federal People's Republic of Yugoslavia 